\title{
Analysis of Butyl Butyrate Mass Spectrum
}

\author{
Abdalla Mustafa Walwil \\ Correspondence: Abdalla Mustafa Walwil, Department of Chemistry, Arab American University, Palestine.
}

Received: October 29, 2017 Accepted: November 26, 2017 Online Published: January 3, 2018

doi:10.5539/ijc.v10n1p11 URL: https://doi.org/10.5539/ijc.v10n1p11

\begin{abstract}
The aim of this educational work is targeting chemistry students and interested instructors. The presented work will analyze the mass spectrum of butyl butyrate (butyl butanoate). The analysis will concentrate on the mechanisms showing how the characteristic fragments are formed. The mechanisms discussed in this paper include $\alpha$-cleavage, $\beta$-cleavage, McLafferty Rearrangements, first and second proton transfer, a double proton transfer.
\end{abstract}

Keywords: $\alpha$-cleavage, $\beta$-cleavage, McLafferty Rearrangement, base peak, butyl butanoate, proton transfer, double proton transfer, MS spectrophotometer

\section{Introduction}

Butyl butyrate is the second compound to be discussed in a series of MS spectral analysis of organic compounds. The MS spectra for $\alpha$-Ionone and $\beta$-Ionone were analyzed earlier (Walwil, 2017). The intended analysis of MS spectra will cover, besides the current analysis, ester, and the earlier one, ketone, ionones, all other classes includes carboxylic acids, aldehydes, amides, amines, alcohols, ethers, etc. Butyl butyrate was chosen for analysis since its mass spectrum shows many characteristic signals and their analysis is straightforward and easy to follow.

The current work will provide a thorough analysis of the EI-MS spectrum of one flavor aroma compound butyl butyrate. The fragmentation mechanisms of all major peaks will comprehensively be analyzed (Yang, Minkler, Hoppel, \& Tserng, 2006).

Butyl butanoate is the IUPAC name for butyl butyrate. It is an aroma ester found in various kinds of fruits such as berries, strawberry, apple and banana. Butyl butyrate is used industrially as sweet flavors for pineapple which is important for food and beverages industries.

The most common methods for preparing esters are esterification and transesterification (Varma \& Madros, 2008). Butyl butyrate can be synthesized by reacting butanoic acid with n-butanol in the presence of an acid catalyst.<smiles>CCCC(=O)O</smiles>

Butanoic acid<smiles>[CH2+]CCCOC1C=C[C@H]1O</smiles>

1-Butanol<smiles>CCCCOC(=O)CCC</smiles>

(Esterification)<smiles>CCCCOC(=O)CCC</smiles>

Butyl butanoate

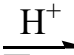

Ethanol

\section{Butyl butanoate}

Since alkanoyl chlorides are readily made from the corresponding acids by using either thionyl chloride or phosphorous tri or pentachloride, then, the sequence $\mathrm{R}_{1} \mathrm{CO}_{2} \mathrm{H} \rightarrow \mathrm{R}_{1} \mathrm{COCl} \rightarrow \mathrm{R}_{1} \mathrm{CO}_{2} \mathrm{R}$ is found to be a better method for esterification. This method is faster and avoids the troubles associated with the equilibrium of acid-catalyzed formation (Loudon, 2002) (Clark, 2015). 
<smiles>CCCC(=O)O</smiles>

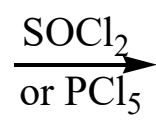<smiles>CCCC(=O)Cl</smiles><smiles>CCCCOC(=O)CCCCO</smiles>

In contrast to all spectroscopic machines, mass spectrometry involves no absorption of electromagnetic radiation. Mass spectrometry is one of the most important techniques for determining molecular masses. The objective here is the study of the mechanisms of how the characteristic fragments of butyl butanoate are formed and how it can be applied to structure elucidation. In a mass spectrometer, a sample of butyl butyrate will be vaporized in a vacuum and bombarded with an electron beam of high energy (around 70 electron volts); the results will knock an electron off of the molecules and break them into smaller fragments, charged and neutral ones (Solomons, \& Fryhle, Organic Chemistry).

\section{Spectral Analysis}

According to Figure 1, the main characteristic peaks of butyl butanoate observed are at $\mathrm{m} / \mathrm{z}=116,101,89,88,73,71$, $61,60,57,56,43$, and 29; the numbers indicated on the signals represent the mass of ions of the corresponding charged fragments. The peaks at $\mathrm{m} / \mathrm{z}=15,29,43,57$, and 71 are known as cluster peaks (fragments). Note that the main peak, the molecular ion peak, is missing; this is expected for some esters, especially those esters of alcohols larger than four carbon atoms (the carbonyl oxygen $\mathrm{R}$ group). The absence of the molecular ion, $\mathrm{M}^{+}$, peak indicates that it is somewhat unstable and fragments too quickly to be observed. The ion fragment requires around $5 \times 10^{-5}$ seconds to reach the detector and for a signal to be observed (Pavia, Lampman, Kriz, \& Vyvyan, Introduction to Spectroscopy).

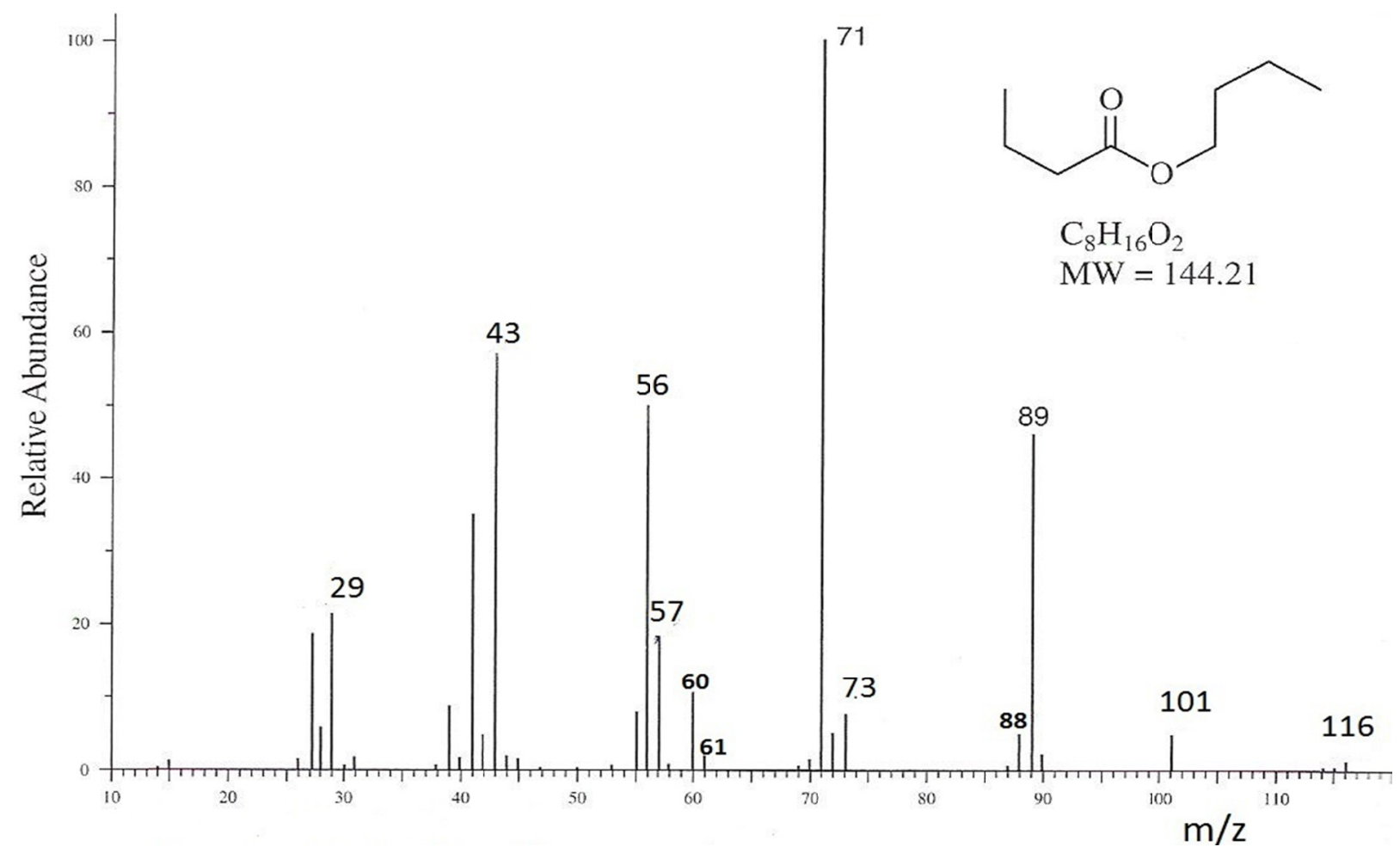

Figure 1. EI-MS of Butyl butanoate

\section{The Structures of the Major Fragment Ions}

Once the gaseous molecules of the studied compound are bombarded with a beam of high-energetic electron, a valence electron from the gas-phase molecules will be dislodged leaving them with positive charges and unshared electrons $\left(\mathrm{M}^{+}\right)$; the charged ones will further break into smaller fragments. Table 1 represents the major characteristic ion fragments (Vollhardt, \& Schore, Organic Chemistry/Structure and Function): 
Table 1. The structure and the weight of the main fragment ions for butyl butanoate<smiles>CCCCOC(=O)CCC</smiles>

$\underline{m} / \underline{z}$<smiles>CCCC=[O+]CC</smiles>

$\underline{m} / \underline{z}$

144<smiles>CCCCOC(=O)CCC</smiles><smiles>C=C(O)[OH2+]</smiles><smiles>C=C([OH2+])OCCCC</smiles><smiles>C=C([O-])[OH2+]</smiles><smiles>CCCCO[C-]=[O+]</smiles><smiles>C=C([O])O</smiles><smiles>CCCC(O)=[OH+]</smiles><smiles>[CH2+]CCC</smiles>

89<smiles>CCCC(=O)O</smiles><smiles>[CH2+]CC</smiles><smiles>CCCC[OH2+]</smiles><smiles>C=C[OH+]</smiles>

\section{Spectral Mechanism}

The EI, electron ionization, is the ion source used in the study. An electron will be knocked off of the vaporized sample of butyl butanoate when bombarded with a beam of high-energetic electrons (usually $70 \mathrm{eV}$, or about $1600 \mathrm{Kcal} / \mathrm{mol}$ ) leading to the formation of a radical-positively charged ion called the molecular ion, $\mathrm{M}^{+}$, as shown below.

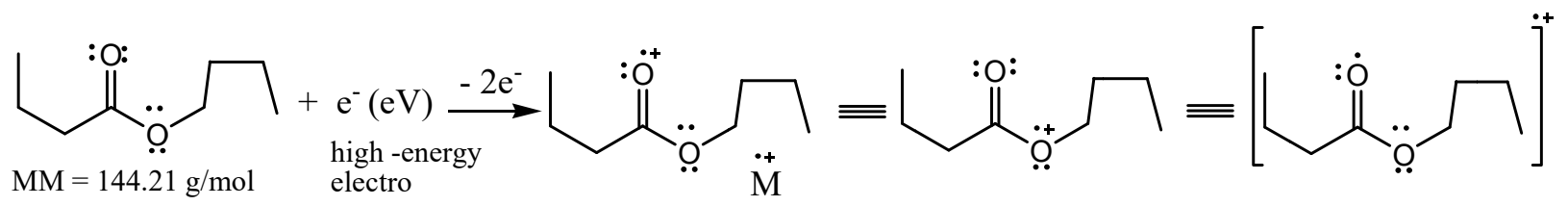

Usually and for most organic compounds, the molecular ions break down into fragments due to the high energy imparted on them in the ionization chamber. The butyl butanoate molecular ions or the corresponding fragments may fractionate in different characteristic ways, a neutral and a charged fragments. The MS spectrum for butyl butanoate showed many characteristic peaks due to one or more of these mechanisms: McLafferty Rearrangement, $\alpha$-cleavage, or $\beta$-cleavage, or $\gamma$ - Proton Transfer Processes (Solomons, \& Fryhle, Organic Chemistry).

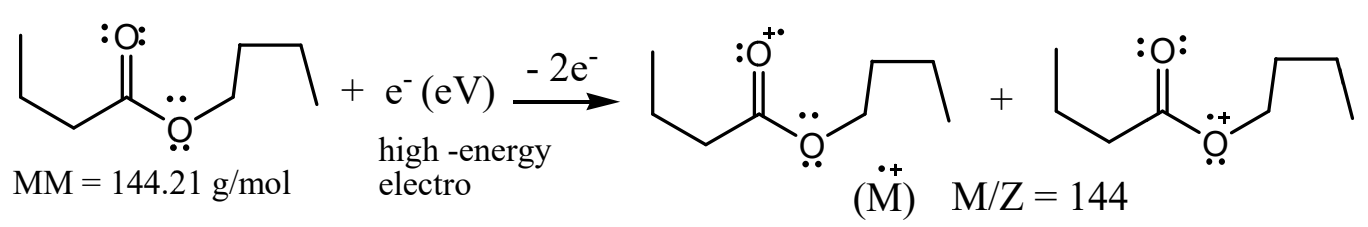




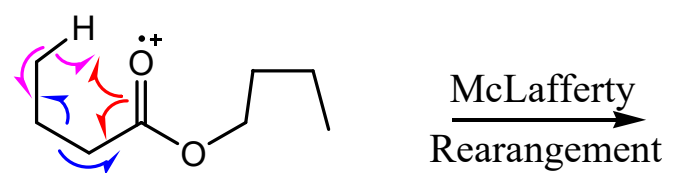

$\mathrm{M} / \mathrm{Z}=144$ $\int_{0}^{+\bullet H}+$

$\mathrm{M} / \mathrm{Z}=116$<smiles>CCCCO[C-]=[O+]</smiles>

$\mathrm{M} / \mathrm{Z}=101$

$\stackrel{\alpha-\text { cleavage }}{\longrightarrow}$

$\mathrm{M} / \mathrm{Z}=144$

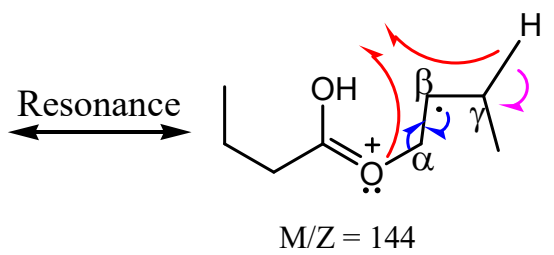

$\mathrm{M} / \mathrm{Z}=144$ $\underset{\text { Rearangemen }}{\stackrel{\text { McLafferty }}{\longrightarrow}}$

Rearangement<smiles>CCCC(=O)[O-]</smiles>

$\mathrm{M} / \mathrm{Z}=88$<smiles>CCC[CH+]OCCCC</smiles><smiles>CCCCO</smiles>
$\mathrm{M} / \mathrm{Z}=71$<smiles>C=C(O)[OH2+]</smiles>

$+$

/l

(Eq. 8) 


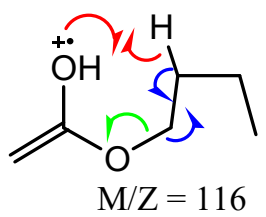<smiles>Oc1ccccc1O</smiles>
$\mathrm{M} / \mathrm{Z}=88$<smiles>CCCCOC(=O)CCC</smiles>
$\mathrm{M} / \mathrm{Z}=144$

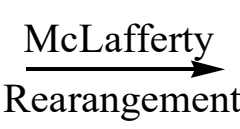

$\underset{\text { Rearangement }}{\stackrel{\text { McLafferty }}{\longrightarrow}}$<smiles>C=C([O-])[OH2+]</smiles><smiles>c1ccccc1</smiles><smiles>C=CCC</smiles>

(Eq. 9a)

$\mathrm{M} / \mathrm{Z}=60$

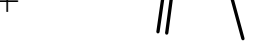

$+\quad \square$<smiles>C=CCC</smiles>

(Eq. 10)<smiles>CCCCC(=O)O</smiles>

$\mathrm{M} / \mathrm{Z}=43$<smiles>C=C</smiles>

(Eq. 12b)
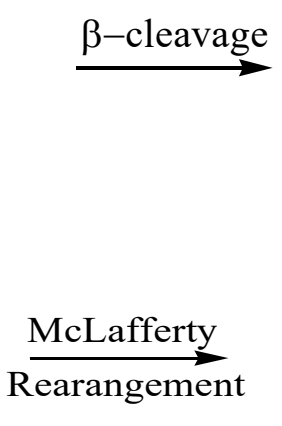

$\mathrm{M} / \mathrm{Z}=144$<smiles>C1=[O+]CC2CCCCC2C1</smiles>

$\mathrm{M} / \mathrm{Z}=71$<smiles>[C+]=CC=C</smiles><smiles>CCCCOC=O</smiles>

$+$

$M / Z=43$
$\mathrm{M} / \mathrm{Z}=56$

\section{Discussion}

Regarding the butyl butyrate's mass spectrum, the molecular ion peak is not observed which indicates that it was fragmented before it got to the detector, meaning that it could not live the $5 \times 10^{-5}$ of a second fraction required to get processed.

Bond Cleavages of molecules in the EI-Mass Spectrophotometer will lead to charged and neutral fractions. Those cleavages which considered characteristic cleavages inflected on butyl butyrate are: $\alpha$-cleavage, $\beta$-cleavage (known as inductive cleavage), McLafferty Rearrangement, a proton transfer and a double proton transfer.

Only the ionized fragments can be detected and leads to singlet peaks as a function of their abundance to $\mathrm{m} / \mathrm{z}$ ratio. The height of a peak, its intensity, depends on the number of ions formed; the most abundant ions will give rise to the tallest peak called the base peak. Usually the highest $\mathrm{m} / \mathrm{z}$ ratio signal of the spectrum is the molecular ion, $\mathrm{M}^{+}$, if appears, not to confuse with the isotopic peaks, $\mathrm{M}+1$ and $\mathrm{M}+2$. Usually the isotopic peaks are in much smaller intensity relative to the $\mathrm{M}^{+}$peak (Walwil, 2017).

For the analysis of the target molecule spectrum, I chose the sequential analyses of the mechanisms in correspondence to the formation of the heaviest fragment ions, Eq1, to the lightest, Eq12. The butyl butanoate molecular ions undergo 
McLafferty rearrangements and $\alpha$-cleavage, the most common fragmentation usually occurs, to form the positively-charged radical moiety at $\mathrm{ms} / \mathrm{z}=116$ along with ethylene and the acylium ion at $\mathrm{m} / \mathrm{z}=101$ along with propyl radical respectively. (Eq. $2 \&$ Eq. 3)

A double proton transfer of the molecular ion leads to a butenyl radical and the corresponding diol-like fragment ion of weight $\mathrm{m} / \mathrm{z}=89$. As indicated in equation 4 , the first $\gamma$-proton transfer leads to the oxonium intermediate which is resonance stabilized, followed by a second $\gamma$-proton transfer (McLafferty-like rearrangement). (Eq. 4)

A second McLafferty rearrangement takes place on the side of the carbonyl oxygen $\mathrm{R}$ group of the molecular ion, the butyl attached to the carbonyl oxygen, to form butenyl radical and the fragment ion at $\mathrm{m} / \mathrm{z}=88$. (Eq. 5)

Through $\beta$-cleavage (inductive cleavage), the carbonyl carbon-oxygen bonds break leading to the loss of acylium radical and the formation of the oxonium cation at $\mathrm{m} / \mathrm{z}=73$. (Eq. 6)

Through $\alpha$-cleavage of the molecular ion, the carbonyl carbon-oxygen bonds break readily because the resulting acylium carbocation at $\mathrm{m} / \mathrm{z}=71$ is resonance stabilized which leads to the most abundant fragment ions. (Eq. 7)

The fragmented ions of $\mathrm{m} / \mathrm{z}=89$ undergo another fragmentation through McLafferty rearrangements to form the positively-charged ions at $\mathrm{m} / \mathrm{z}=61$. (Eq. 8 )

Usually, the fragment ions themselves might break into a second or a third mode of fragmentations. Both of the followings represent the second mode of fragmentation and they are in the type of McLafferty Rearrangements. Although their contributions to the corresponding peak intensity is weak, but it's worth presenting since it is considered characteristics. Both fragment ions at $\mathrm{m} / \mathrm{z}=116$ and 88 undergo McLafferty rearrangements to form the corresponding fragment ions at $\mathrm{ms} / \mathrm{z}=60$ and 60 respectively. (Eq. $9 \mathrm{a}$ and $9 \mathrm{~b}$ )

Furthermore, the carbon-oxygen bonds of the molecular ions break inductively (through $\beta$-cleavage) to form the butyl cation at $\mathrm{m} / \mathrm{z}=57$. (Eq. 10)

A $\gamma$-proton-transfer of the ester's alkyl moiety of the molecular ions followed by $\beta$-cleavages results in the loss of the diol-like moiety and the formation of butyl radical cation at $\mathrm{m} / \mathrm{z}=56$. (Eq. 11)

Both $\beta$-cleavages of the molecular ions, $\mathrm{M}^{+}$, of the carbonyl carbon-carbon and McLafferty rearrangements of the fragment ions at $\mathrm{m} / \mathrm{z}=71$ lead to the formation of the positively-charged ions at $\mathrm{ms} / \mathrm{z}=43$ and 43 respectively. (Eq. 12a \& 12b)

\section{Conclusion}

The novelty of this work, as an educational work, is that the EI-MS spectrum of butyl butanoate is analyzed thoroughly. No other source found where all characteristic fragment ions mechanistically discussed thoroughly.

As known, the mode of fragmentation is characteristic and hence predictable. For butyl butyrate the mechanisms involved in the analysis were $\alpha$-cleavage, $\beta$-cleavage, McLafferty Rearrangements, first and second proton transfer. There are more modes that will be discussed in further studies such as Two-Proton Cleavage and Retro Diels-Alder Cleavage. The next study will cover the MS spectra of butanamide and methyl 2-methylbutanoate.

\section{References}

Clark, J. (2015). https://chemguide.co.uk/organic props/alcohols/esterification

Loudon, G. M. (2002). Organic Chemistry, Oxford: Oxford University Press.

Pavia, D. L., Lampman, G. M., Kriz, G. S., \& Vyvyan J. R. Introduction to Spectroscopy, $4^{\text {th }}$ Ed. Brooks/Cole, 418-450.

Solomons, T. W., \& Fryhle, C. B. Organic Chemistry. $9^{\text {th }}$ Ed. Wiley, 401-413.

Varma, M. N., \& Madros, G. (2008). J. chem. Technol. Biotechnol, 83(8), 1135-1144. https://doi.org/10.1002/jctb.1897

Vollhardt, K. P., \& Schore, N. E. Organic Chemistry/Structure and Function, $3^{\text {rd }}$ Ed. W. H. Freeman and Company, 907-918.

Walwil, A. M. (2017). International Journal of Chemistry, 9(3), 61-66. https://doi.org/10.5539/ijc.v9n3p61

Yang, S., Minkler, P., Hoppel, C., \& Tserng, K. Y. (2006). Journal of the American Society for Mass Spectrometry, 17(11), 1620-1628. https://doi.org/10.1016/j.jasms.2006.07.004

\section{Copyrights}

Copyright for this article is retained by the author(s), with first publication rights granted to the journal.

This is an open-access article distributed under the terms and conditions of the Creative Commons Attribution license (http://creativecommons.org/licenses/by/4.0/). 